\title{
Comparing different shallow geophysical methods in a tidal estuary, Verdronken Land van Saeftinge, Western Scheldt, the Netherlands
}

\author{
T. Missiaen ${ }^{1,2,{ }^{*}}$, E. Slob ${ }^{1}$ \& M.E. Donselaar ${ }^{1}$
}

1 Dept. of Geotechnology, Delft University of Technology, Mijnbouwstraat 120, 2628 RX Delft, the Netherlands.

2 Renard Centre of Marine Geology, University of Gent, Krijgslaan 281-S8, 9000 Gent, Belgium.

* Corresponding author. Email: t.missiaen@citg.tudelft.nl

Manuscript received: June 2007; accepted: March 2008

\begin{abstract}
In order to validate existing models of sedimentation in active sedimentary environments, detailed stratigraphic information is indispensable. Near-surface geophysical methods provide a means to acquire high-resolution images of the stratigraphic succession in the shallow subsurface. Land-based and marine methods have been tested in the Verdronken Land van Saeftinge. This intertidal flat area is cut by numerous tidal gullies, and high tidal amplitudes enable the application of different techniques at various water levels. Data acquisition focused on the upper $10-20 \mathrm{~m}$ of the active sediment bodies. Applied techniques include high-resolution seismic acquisition, geo-electrical methods (DC resistivity), electromagnetic techniques, CPT, and manual drilling. In general the acoustic methods allowed more reliable and detailed interpretation of the sedimentary structures than the electric/electromagnetic methods. The latter suffered from the effect of tidal action and salt-water intrusion, and their application on land proved very strenuous. CPT and shallow cores provided valuable ground-truth information. The results clearly indicate that no single technique can provide all the answers. Only an integrated use of (complementary) methods will allow getting a better grip on the sedimentary architecture and preservation potential in active estuarine sedimentary environments.
\end{abstract}

Keywords: Tidal estuary, intertidal flat, land-sea boundary, shallow geophysics, Western Scheldt

\section{Introduction}

The estuarine environment is in dynamic equilibrium with the relative sea level. Minor changes in sea level have a direct impact on the estuarine accommodation space, and hence on the hydrodynamic processes, sediment supply, morphology and preservation potential of sediment bodies therein. Predictive models of the morphodynamic development of the estuary in space and time require input data sets that consider size, shape, spatial position and preservation potential of estuarine sediments in the geological record.

Geophysical methods have the potential to yield this detailed information in the whole range from supra-tidal marsh to sub-tidal channels. However, the land-sea-boundary often remains a blank spot, because to date no reliable match exists between land-based and marine geophysical methods. The aim of this paper is to assess the most promising geophysical methods (or combination of methods) in the supra- to sub-tidal estuarine realm where the same sediment bodies may be imaged both from the land and the sea. The aim is reached by a comprehensive testing program in which landbased and marine geophysical methods are integrated.

\section{Geological setting}

The test site is located in the Verdronken Land van (= Drowned Land of) Saeftinge at the southern rim of the Western Scheldt Estuary, the Netherlands (Fig. 1). The estuary forms the southern part of the Rhine-Meuse-Scheldt delta, and evolved from the Honte tidal basin which formed a vast marsh area since the early Middle Ages. The Honte became connected with the Scheldt River north of Antwerp between ca. $800 \mathrm{AD}$ and ca. $1100 \mathrm{AD}$ and evolved into the new river mouth of the Western Scheldt (Vos \& Van Heeringen, 1997). By the end of 


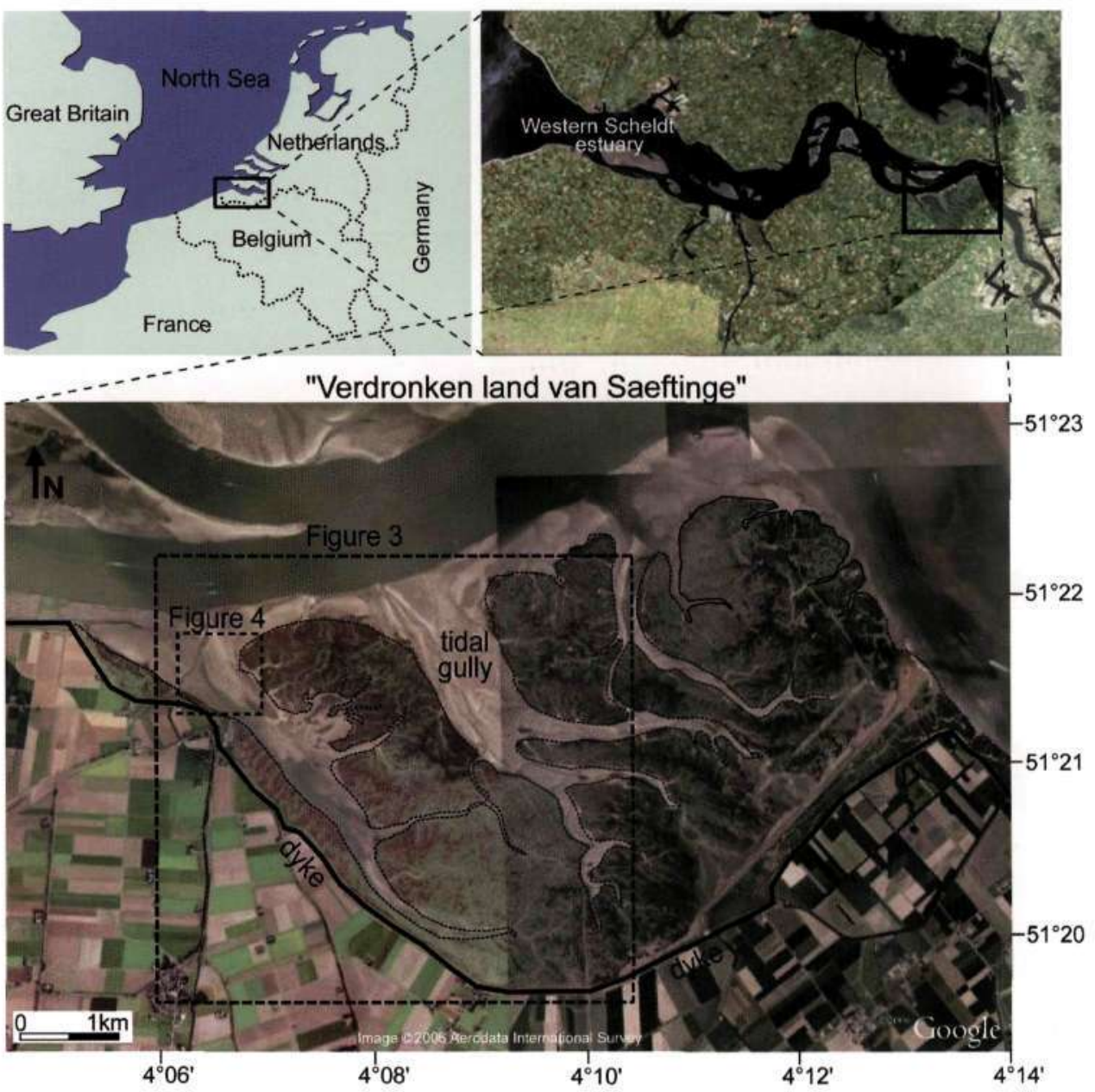

Fig. 1. Overview map and location of the tidal flat area Verdronken land van Saeftinge' in the Western Scheldt estuary on the Belgian-Dutch border (Google Earth'm image).

the 16th century the Western Scheldt had become the main outlet of the river Scheldt. The Verdronken Land van Saeftinge is the only remaining extensive tidal marsh in the present-day Western Scheldt. It consists of approximately 3000 ha of supratidal salt marshes, inter-tidal mudflats and sandy shoals, cut by numerous tidal channels and creeks (Fig. 1).

The stratigraphy in the Saeftinge area reflects the Pleistocene-Holocene glacio-eustatic development. Aeolian sand deposits of the Pleistocene Boxtel (formerly Twente) Formation were truncated by fluvial valleys during the Weichselian glacio-eustatic lowstand (De Gans and Van Gijssel, 1996). During the subsequent glacio-eustatic sea level rise the Pleistocene surface gradually flooded and at the onset of the Holocene evolved in a coastal marsh. An extensive but discontinuous (Vos \& Van Heeringen, 1997) peat layer, the Basal Peat, formed. With continuing sea level rise tidal channels developed (Naaldwijk Formation, Wormer member (formerly Westland formation, Calais deposits)), thereby locally eroding the Basal Peat. The sandy and clayey Wormer deposits are often poor in organic matter, and frequently exhibit a grey or blackish colour, due to sulphate reduction (Vos \& Van Heeringen, 1997). The deceleration of the rate of sea level rise around 5500 BP caused the gradual infill of the tidal area with fluvial and marine-derived sediment. The area transformed to a coastal marsh and a second peat layer, the Holland Peat was formed. The most recent deposits (3000 BP to present) consist of tidal sand and clay (Naaldwijk Formation, Walcheren member formerly Westland Formation, Dunkerque Deposits, Weerts et al., 2000). They locally contain peat detritus and even lumps of peat, resulting from erosion of the Holland Peat or the Basal Peat. The average thickness of the Holocene in the Saeftinge area ranges roughly between 10 and $20 \mathrm{~m}$ (Ebbing \& Laban, 1996).

Recent sedimentation has been strongly affected by dike building, which seriously reduced the marine influence. The first dikes date from around $1200 \mathrm{AD}$, and by the 14 th century most of the area was embanked (De Kraker, 1997). Exceptional tidal floods and cutting of the dikes (for military purposes) inundated large parts at the end of the 16th century (Fig. 2c). 0ver the next centuries the land was gradually reclaimed (Fig. 2b). Around 1910 the present dike was finalized (Fig. 2a). The supply of large volumes of sand and mud resulted in rapid expansion of the salt marshes (van der Spek, 1997).

\section{Data acquisition and methods}

Geophysical data acquisition in the Verdronken Land van Saeftinge primarily focused on the top $10-20 \mathrm{~m}$ of the Holocene succession. The aim was to acquire a highly detailed image of 


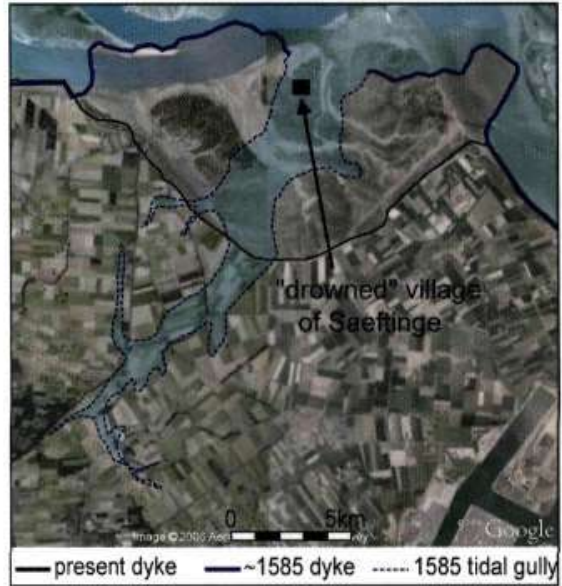

a.

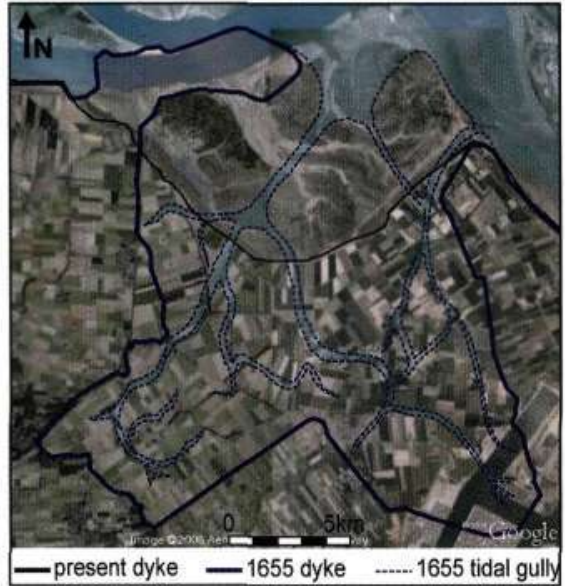

b.

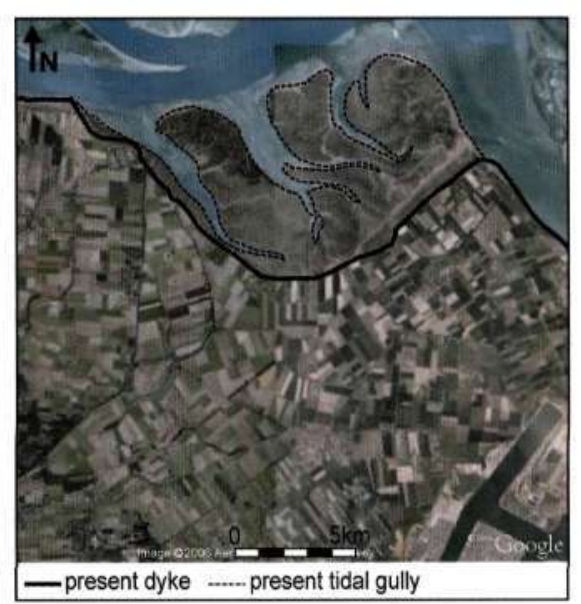

c.

Fig. 2. Reconstruction of the dikes and main tidal gullies in the Saeftinge area in the 16th and 17th century. Background map Google Earth'm image. a. Dike extension and gully system around 1585 AD (based on De Kraker, 1997). Cutting of the dike for military purposes in 1583-1584 resulted in a large tidal inlet. The black rectangle marks the location of the 'drowned' village of Saeftinge. b. Dike extension and gully system around 1655 AD (based on the map 'Zelandia Comitatus Novissima Tabula' by Zacharias Roman, modified after van der Spek, 1997). Large parts were still under marine influence. c. Present dike and gully system.

the subsurface structures and sediment geometries and in addition, where possible, to obtain information on the physical characterisation and sediment properties. To this end the application of shear-wave measurements was essential, also in view of the expected presence of shallow gas (S-waves are not affected by the presence of gas in the sediments). In order to validate the geophysical remote sensing results a number of in-situ groundtruthing investigations were carried out.

The mean tidal range in the Saeftinge area is around $4.5 \mathrm{~m}$; mean spring and neap tides are $5.2 \mathrm{~m}$ and $3.6 \mathrm{~m}$ respectively (Verlaan et al., 1997). The high tidal amplitudes enabled to apply different techniques at different water levels at the same location. During high tide marine geophysical data were obtained from the major tidal channels and creeks, whereas during low tide land-based shallow geophysical data could be obtained from the salt marshes and exposed sand bars. However the difficult access and terrain conditions seriously limited the possible techniques and equipment. Being a nature reserve, access was furthermore often restricted and occasionally temporarily forbidden (e.g. during the breeding season).

The different geophysical techniques that were tested in the Verdronken Land van Saeftinge are:

- Marine sub-bottom profiling (2D and pseudo-3D) in the largest channels.

- Seismic reflection measurements on an intertidal sand bar in the main channel.

- Geo-electrical and transient electromagnetic (TEM) measurements on the marsh and on the intertidal sand bar.

- Marine geo-electrical measurements in the largest channels.

- Cone penetration tests (CPT) on the intertidal sand bar in the main channel.

- Manual coring on the marsh and on the intertidal sand bar.
The location of the different geophysical surveys is shown in Fig. 3. The test sites were mainly located in the westernmost part of the Verdronken Land van Saeftinge, as this part was easiest accessible. Marine investigations were restricted to $\max$. $4 \mathrm{~h}$ working windows due to limited accessibility of the tidal harbour. It was not physically possible to carry heavy equipment over long distances in the salt marsh. Access to the sand bars in the main channel was only possible using shallow draft boats, making landfall during falling tide. Lightweight equipment could eventually be transported by parties on foot, wading across the tidal channel at low tide.

Comparison and integration of the results mainly focused on two small areas in and along the main western channel Speelmansgat, (see Fig. 3). Area 1, in the north, contains 2D marine seismic data, resistivity data, and CPT data. Area 2, in the south, contains marine and land-based seismic data, resistivity data, and shallow core data.

\section{Marine reflection seismic investigations}

A number of seismic profiles were recorded at high tide in the main tidal gullies using different marine acoustic sources (Cboom, IKB Seistec, $3.5 \mathrm{kHz}$ echosounder, parametric profiler). Due to the shallow water depth the marine surveys were restricted to the deepest part of the gullies. Encountered water depths ranged from less than $1 \mathrm{~m}$ to over $5 \mathrm{~m}$.

The C-boom, a broad band boomer source operating in the $0.3-3 \mathrm{kHz}$ range, was towed behind the boat together with a short receiver array. Resolution is in the order of $50 \mathrm{~cm}$. In the extreme shallow water environment of Saeftinge, often less than $3 \mathrm{~m}$ deep, the source proved inadequate as the array length $(1 \mathrm{~m})$ and offset $(1-2 \mathrm{~m})$ caused destructive stacking 


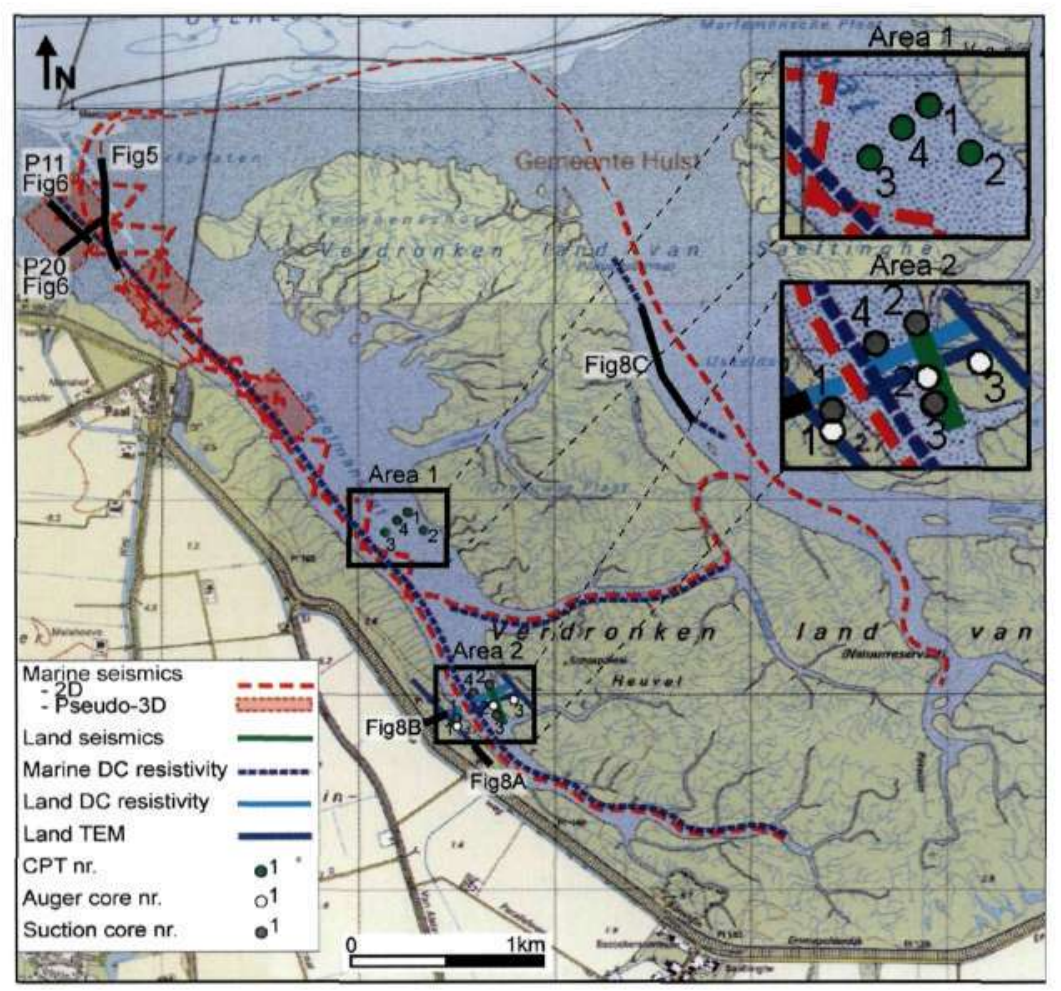

Fig. 3. Schematic overview of the different geophysical investigations carried out in the Verdronken land van Saeftinge (for location see Fig. 1). The thick black lines refer to the illustrations shown in figs 5, 6 and 8. The two black rectangles (Area 1 and Area 2) refer to Figs 10 and 11. Topographic map Topografische Dienst Kadaster, Emmen. of the signals. In the deeper parts of the channels the recorded boomer data were of good quality. The IKB Seistec boomer uses a built-in line-in-cone receiver for detection of the acoustic signal which avoids spatial aliasing problems. It combines high frequencies $(5-6 \mathrm{kHz})$ with a broad bandwidth $(1-8 \mathrm{kHz})$. Vertical resolution is generally between $25-30 \mathrm{~cm}$.

The single-frequency echosounder has a mean peak frequency of $3-4 \mathrm{kHz}$ and a relatively narrow bandwidth. The source transducer also acts simultaneously as a receiving transducer. Vertical resolution is typically $<50 \mathrm{~cm}$. In extreme shallow water $(<3 \mathrm{~m})$, however, the long pulse length of the transducer caused interference between the outgoing and incoming signal which seriously deteriorated the data quality. The non-linear parametric echosounder simultaneously transmits two signals of slightly different high frequencies, their interaction creating a new difference frequency signal. The latter is marked by a large band width and short signal length, which allows good use in very shallow water and results in a very high vertical resolution $(\sim 15-20 \mathrm{~cm})$.

\section{Terrestrial reflection seismic investigations}

Reflection seismic trials were carried out at low tide on a sand bar in the westernmost tidal channel (for location see Fig. 3). It was expected that the shallow water table at the tidal flat would result in a low attenuation of seismic waves, and therefore allow a good resolution of shallow target boundaries. Earlier reflection profiling tests on a beach and tidal flat in the SW of the Netherlands had demonstrated the applicability of the technique (e.g. Jongerius \& Helbig, 1988, Ghose et al., 1997). Walk-away ${ }^{\star}$ spread records of some $80 \mathrm{~m}$ long were recorded using the following sources: S-wave vibrator, $\mathrm{P}$-wave vibrator, sledgehammer, drop weight $(25 \mathrm{~kg})$, and P-hammer.

Geophone spacing was $25 \mathrm{~cm}$, with a minimum source-receiver offset of resp. $50 \mathrm{~cm}$ and shot point interval of $0.5 \mathrm{~m}$. According to Baker et al. (1999) this set-up should allow to observe seismic reflections with low $\mathrm{P}$-wave velocities from very shallow depths. Sampling rate was $4 \mathrm{kHz}$ for a total record length of $1 \mathrm{~s}$. Vibrator sweep frequency was $10-1000 \mathrm{~Hz}$ (P-wave vibrator) and 20 $400 \mathrm{~Hz}$ (S-wave vibrator). Data processing of the walk-away records included amplitude recovery, automatic gain control (AGC), air blast attenuation (especially on P-wave data), surface wave suppression, bandpass filtering, signal-to-noise filtering, top muting, and normal move-out (NMO) correction.

\section{Geo-electrical investigations on land}

Direct current (DC) resistivity profiling was conducted on the supra-tidal marsh and in the main tidal channel using the AGI SuperSting acquisition system (for location see Fig. 3). Dipoledipole and inverse-Schlumberger arrays were tested with different electrode spacing $(1 \mathrm{~m}-2 \mathrm{~m})$ for a total number of 84 electrodes. Although the $1 \mathrm{~m}$ spacing generally should allow a higher resolution, its application proved very time-consuming and the stakes were almost short-circuited due to the highly saline environment. Even at $2 \mathrm{~m}$ stake spacing the stakes had to be covered by isolation tape leaving only the end points of the stake free to emit current and measure potential differences.

- In a walk-away set-up measurements are carried out with increasing distance between the source and receivers. 
The dipole-dipole array proved to be slightly more sensitive to horizontal variations in resistivity compared to the inverseSchlumberger array. Measured apparent resistivity values (in $\mathrm{Ohm} \cdot \mathrm{m}$ ) were converted into true resistivity sections using the Earth Imager inversion software.

In coastal areas the electrical resistivity, or its inverse, electrical conductivity, will mainly be a function of the sediment porosity and pore-water salinity (Maillet et al., 2005 and references therein). The latter will not only depend on the seawater salinity but will also be influenced by freshwater precipitation (especially on the marsh) and the level of the groundwater table. Water salinity in the Saeftinge area is highly variable, ranging from brackish $(5-18 \mathrm{~g} / \mathrm{l})$ to salty $(>18 \mathrm{~g} / \mathrm{l})$, depending on the tide, river discharge, wind, and also season (salinity in summer/fall is generally higher than in winter/ spring) (Van Damme et al., 2005).

\section{Electromagnetic investigations on land}

TEM measurements were carried out at roughly the same site as the DC resistivity profiles (for location see Fig. 3), using the TEM-FAST 48 acquisition unit. Three different loop sizes were tested: $6.25 \mathrm{~m}, 12.5 \mathrm{~m}$, and $25 \mathrm{~m}$ (spacing between soundings resp. 3,5 and $10 \mathrm{~m}$ ). The use of an extremely small antenna was justified by the low soil resistivity $(<10 \mathrm{0hm} \cdot \mathrm{m})$. Increasing loop sizes resulted in a deeper penetration but also lower resolution. The smallest loop size inversions, however, generally proved less reliable due to lower quality data. Measured apparent resistivity values were converted into true resistivity sections using the program TEM-researcher.

\section{Marine resistivity investigations}

Marine DC resistivity data were recorded at high tide in two main tidal gullies (for location see Fig. 3) using the AGI SuperSting acquisition unit. The layout involved a dipole-dipole array with 2 current electrodes and 9 potential electrodes, and $6 \mathrm{~m}$ electrode spacing was used to maximize penetration, while sacrificing lateral resolution. The cable was towed just below the water surface and the first electrode was located at a distance of $15 \mathrm{~m}$ behind the boat. Marine resistivity acquisition proved much more efficient and faster than land acquisition.

\section{Coring and CPT}

Sedimentological data were derived from the shallow subsurface with shallow manual coring and cone penetration tests (CPT). The aim was to pinpoint the key lithofacies transitions in the sedimentary succession that might show up as reflectors in the geophysical record. The cores were taken along the trajectories of the on-land geo-electric and seismic surveys and the CPT were carried out at low tide on an inter-tidal point bar along the marine seismic trajectory (for location see Fig. 3 ).
Coring was carried out with Edelman hand auger and Van der Staaij suction coring devices. Maximum penetration depth of the Auger cores was limited to $2.5 \mathrm{~m}$. The suction corer is a simple, flexible pvc corer that allows quick and easy extraction of uncompacted, water-saturated sandy sediments (Van de Meene et al., 1979; Méndez et al., 2003). Thin layers of clay and peat can be penetrated. Because sampling is rapid the suction corer is ideally fit for work in intertidal areas. Maximum penetration depth was $5.0 \mathrm{~m}$.

Cone penetration tests were carried out in the channel and on the shoal using a $50 \mathrm{kN}$ GeoMil acquisition unit (cone diam. $36 \mathrm{~mm}$ ). Continuous measurements were made of the cone resistance $Q_{c}$ and sleeve friction $F_{s}$ (degree of stickiness). The former is a measure of grain size, whereas the latter is related to clay content (Lunne et al., 1997). The calculated friction ratio $\left(\mathrm{F}_{\mathrm{s}} / \mathrm{Q}_{\mathrm{c}}\right)$ can be converted to lithology. Maximum penetration depth was $13 \mathrm{~m}$.

\section{Sedimentology of the study area}

The geophysical tests were largely carried out in and along the Speelmansgat tidal channel (for location see Figs 1 and 3 ). The channel is wide and deep at its junction with the main channel of the Western Scheldt. To the southeast the tidal channel becomes narrow and shallow, and branches out into a pattern of sinuous tidal creeks that dissect the supra-tidal marsh. The sub-tidal part of the tidal channel has a slightly meandering thalweg. The outer banks (cut banks) of the meander bends are steep and erosional. Inter-tidal point bars (or shoals) fringe the meandering channel on the inner bend (Fig. 4). The channel floor consists of fine-grained sand and is covered with small-scale ripples. The inter-tidal point bars have a gentle dip towards the tidal channel and are covered with flood-oriented linguoid megaripples (Fig. 4). Up-dip the point bars pass into thinly interbedded sand and mud, heterolithic deposits and supra-tidal marsh mud and peat.

The spatial variability of bedforms and lithofacies reflects the spatial and temporal variability of hydrodynamic conditions in the tidal channel environment. The strongest tidal currents cause bed load transport along the sub-tidal channel floor and on the fringing shoals creating sandy megaripples (Nio et al., 1983). Away from the channel the tidal energy dissipates and heterolithic sedimentation takes place. The heterolithic succession reflects the cyclic change of current velocity and direction in the tidal channel, caused by the changing volume of water during tidal pumping (Donselaar \& Geel, 2007). As the water moves in and out of the confined basin with each tidal cycle a regular change occurs of periods when: (a) the tidal current velocity exceeds the threshold velocity for sand transport, and (b) the current velocity falls below the threshold velocity for the settling of mud out of suspension (Allen, 1982; Nio et al., 1983; Nio \& Yang, 1991). 


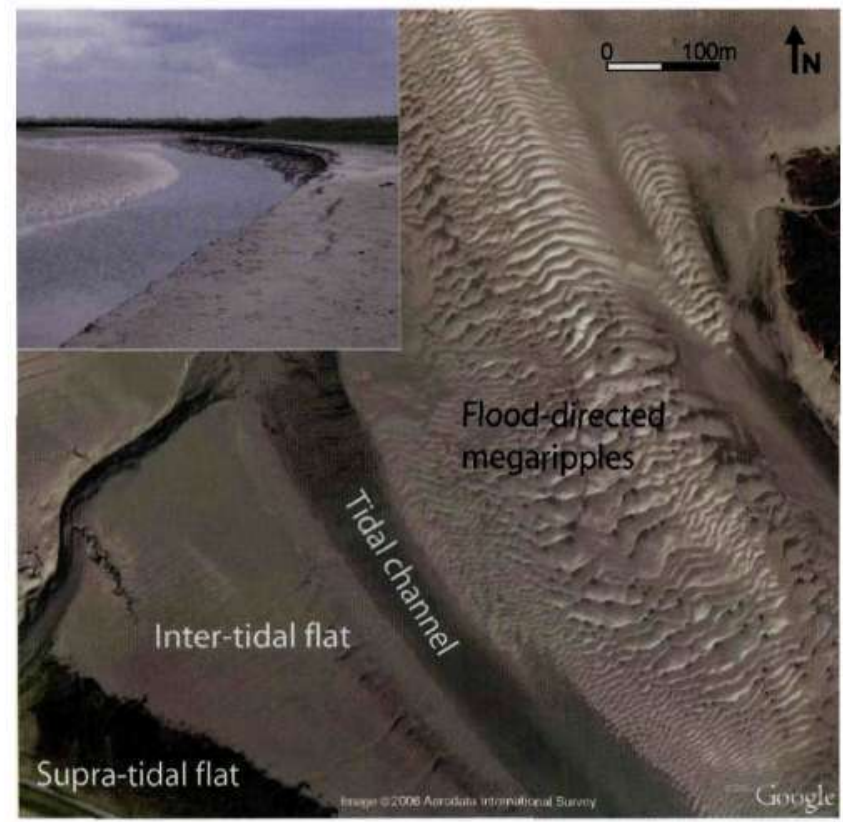

Fig. 4. Close-up of a large megaripple field near the mouth of the tidal channel (Google Earth" image). For location see Fig. 1. The ripples are flood-directed. The inset in the top left shows a meandering tidal channel. The steep outer bank contrasts with the gently dipping inner bend. The point bar is clearly visible on the left.

\section{Results}

\section{Marine reflection seismic investigations}

Examples of seismic profiles recorded with each system and at roughly the same site are shown in Fig. 5 (for location see Fig. 3). The Seistec and parametric profiler provided by far the best results. Both sources allowed resolving the internal structure of the shallow subsurface in high detail. Still penetration often remained limited to a few $\mathrm{m}$, due to the presence of shallow gas (methane). The gas is probably of biogenic origin, produced by bacterial degradation of organic matter. Its origin is most likely to some extent linked to the presence of shallow peat deposits. Locally the gas reaches up to the water bottom. Some gassy patches were observed to shift laterally over time: profiles recorded at the same location but with a few months interval showed a different gas pattern. This could be due to changing pore water salinities within the (organic-rich) sediments - indeed an increasing amount of freshwater may enhance sulphate depletion and therefore stimulate seismic wipe-outs (Kogan \& Paull, 2004).

In general the parametric profiler showed the highest resolution, and this source was therefore used to record a number of dense pseudo-3D networks at the mouth of the westernmost tidal channel (for location see Fig.3). Line spacing varied from $50-80 \mathrm{~m}$ for the large-scale network and $10-20 \mathrm{~m}$ for the three small-scale networks. The results show a detailed visualisation of laterally-stacked channel fills and lateral accretion surfaces (Fig. 6). The steep and erosional outer bend of the channel is clearly observed. The chaotic infilling at the bottom of the paleochannel seems to suggest some minor collapse event.

The densely spaced seismic data clearly demonstrate the high level of heterogeneity and lateral variability in subsurface structure of the tidal flat area, even between sites located merely a few meters apart.

\section{Terrestrial reflection seismic investigations}

A large number of shallow reflectors were observed on the land seismic records. The highest resolution was obtained with the portable S-wave vibrator (Fig. 7). The latter is not surprising, since shear wave velocities $\left(V_{S}\right)$ in soft water-saturated soils are generally very low compared to $\mathrm{P}$-wave velocities (in our case $V_{P} / V_{S}>10$ ), resulting in a much shorter wavelength and therefore higher resolution. Furthermore it is known that shear waves are generally more sensitive to small variations in soil type than compressional waves (Ghose, 2003 and reference therein).

Shallow reflections on the S-wave vibrator data were observed at $\sim 1,3,4,6.5$ and $8 \mathrm{~m}$ depth (Fig. 7a) (corresponding to vertical two-way-time velocity of $1600 \mathrm{~m} / \mathrm{s}$ ). The shallowest reflections observed on the $\mathrm{P}$-wave vibrator data were at 4 and $8 \mathrm{~m}$ (Fig 7b). The shorter wavelength of the shear waves resulted in a faster attenuation. The latter was evident on the field data, where deeper reflections were better observed on the P-wave profiles (Fig. $7 \mathrm{~b}$ ).

The walk-away profiles locally exhibited a strong heterogeneity in seismic quality. Seismic reflectors were often discontinuous and showed a high variation in reflection strength. Since these variations were observed on all walk-away profiles, they are most likely not related to poor source/sediment or poor receiver/sediment coupling. Probably they can be attributed to a high spatial variability and heterogeneous nature of the shallow sandy sediments.

\section{Geo-electrical investigations on land}

The measured resistivity contrasts on the DC profiles were generally very low (Fig. 8a), indicating a highly conductive soil. The high conductivity also resulted in a decrease in reliability (i.e. lower model sensitivities) of the deeper resistivity data. In most cases the reliable penetration depth was limited to roughly $10 \mathrm{~m}$. The obtained sections did not show a clear downward decrease in resistivity values nor did they show any clear horizontal stratification.

A number of shallow, vertically elongated structures with a distinct higher resistivity were observed, reaching up to the surface (Fig. 8a). These seem to be caused by small active tidal channels in the topography, the missing volume of soil generating high resistance 'voids'. Slightly deeper, a large 

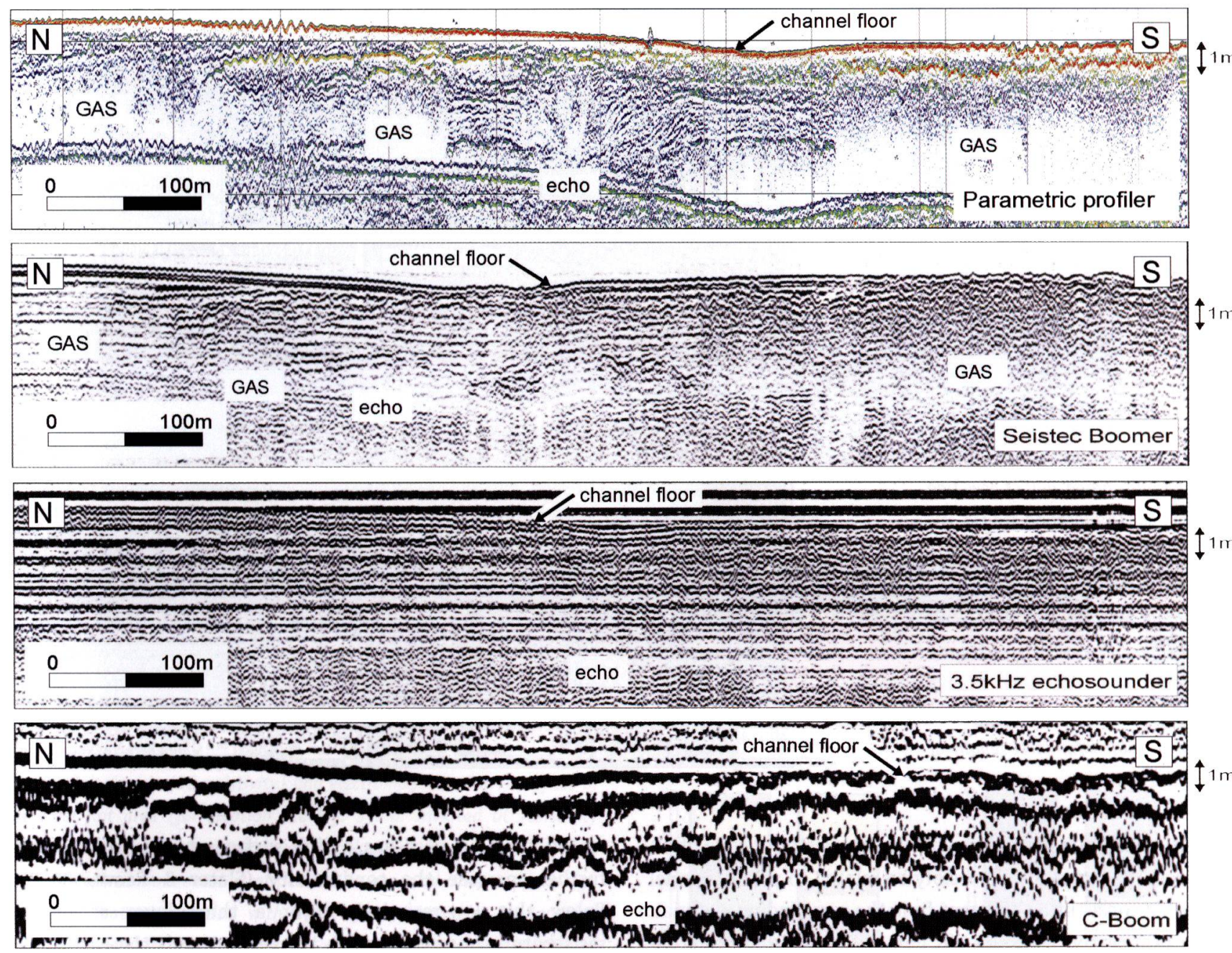

Fig. 5. Marine $2 D$ seismic sections recorded at roughly the same location using different sources (for location see Fig. 3). From top to bottom: parametric profiler, IKB Seistec, $3.5 \mathrm{kHz}$ echosounder, C-Boom. Water depth between 2.5 and $3.5 \mathrm{~m}$. Profile length $\pm 750 \mathrm{~m}$. Both echosounder and C-Boom suffer from a loss in data quality as a result of the extreme shallow water depth. Parametric profiler and Seistec data show a number of shallow reflectors but are often marked by limited penetration, most likely due to shallow gas.
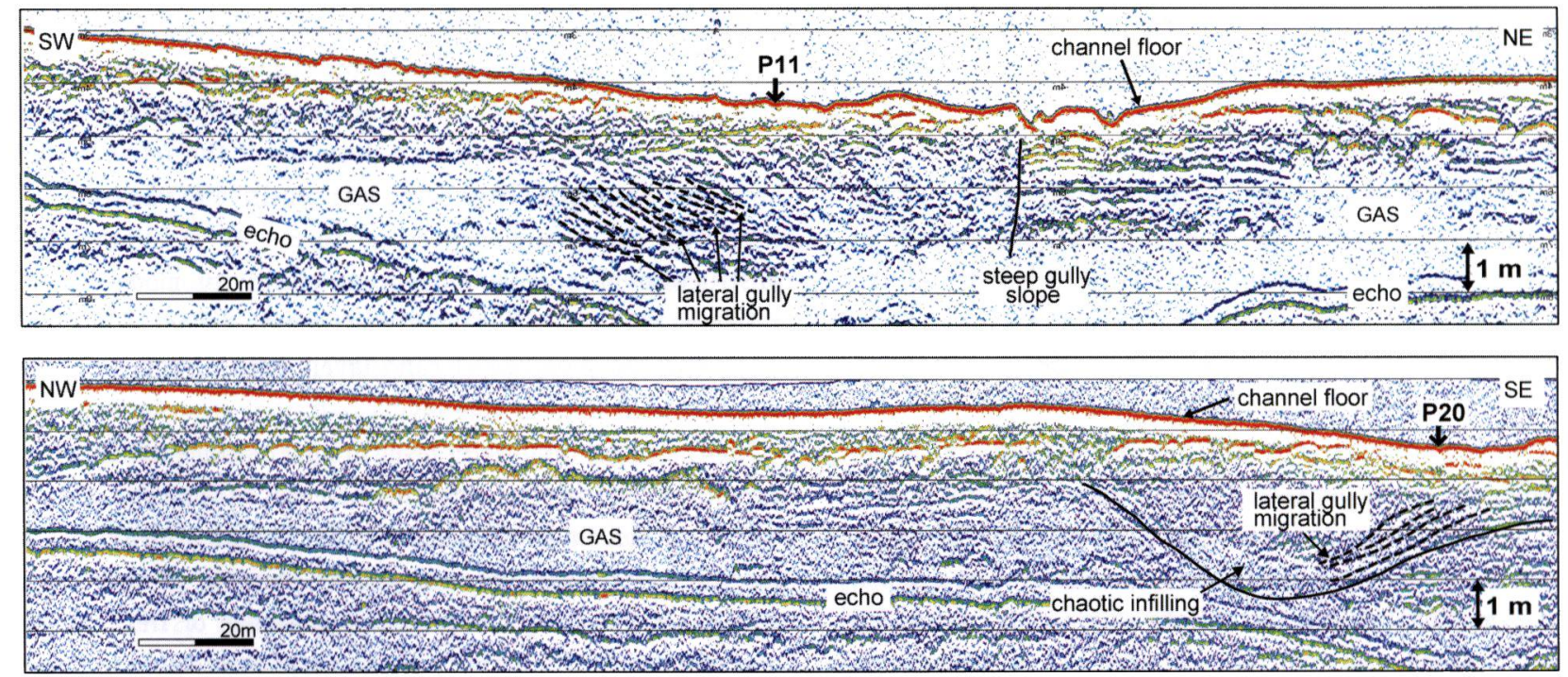

Fig. 6. Parametric profiler records $(10 \mathrm{kHz})$ obtained near the mouth of the Speelmansgat (for location see Fig. 3). Water depth $\sim 4 \mathrm{~m}$. Profile length $\sim 250 \mathrm{~m}$. The profiles show great detail in the shallow stratification, in specific lateral migration of an ancient tidal gully. The steep erosional side marking the outer channel bend stands out clearly on the upper profile. Gassy patches are often seen to cut through the shallow stratification. 


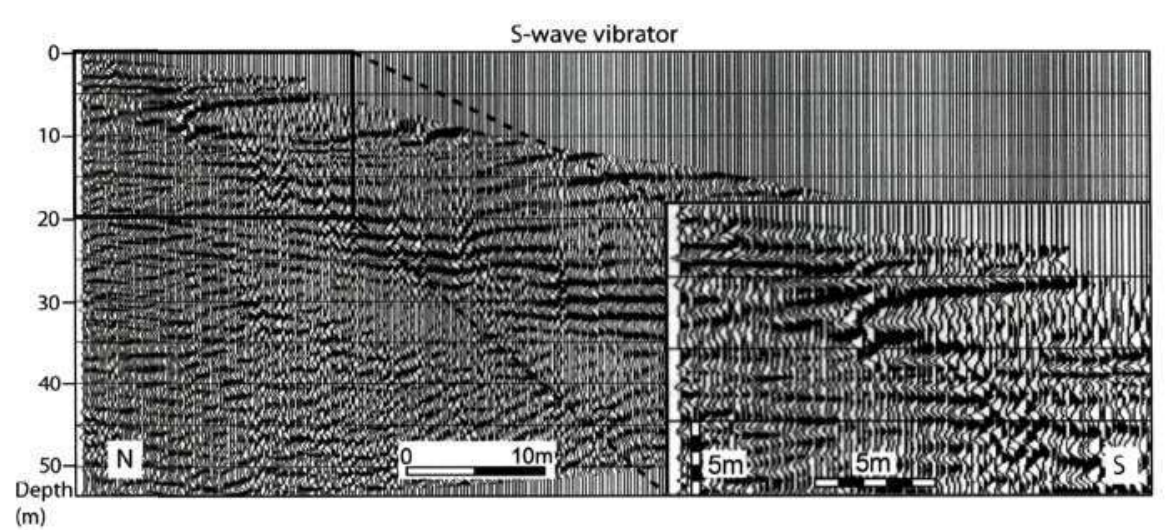

a.

Fig. 7. Results from land seismic investigations carried out at low tide on a sand bar (for location see Fig. 3). A number of reflections are observed in the upper meters. a. Processed walkaway profile recorded with the S-wave vibrator; $b$. Processed walk-away profile recorded with the $P$-wave vibrator. Depth conversion using TWT velocity of $1600 \mathrm{~m} / \mathrm{s}$. Total length of the profiles $\sim 80 \mathrm{~m}$.

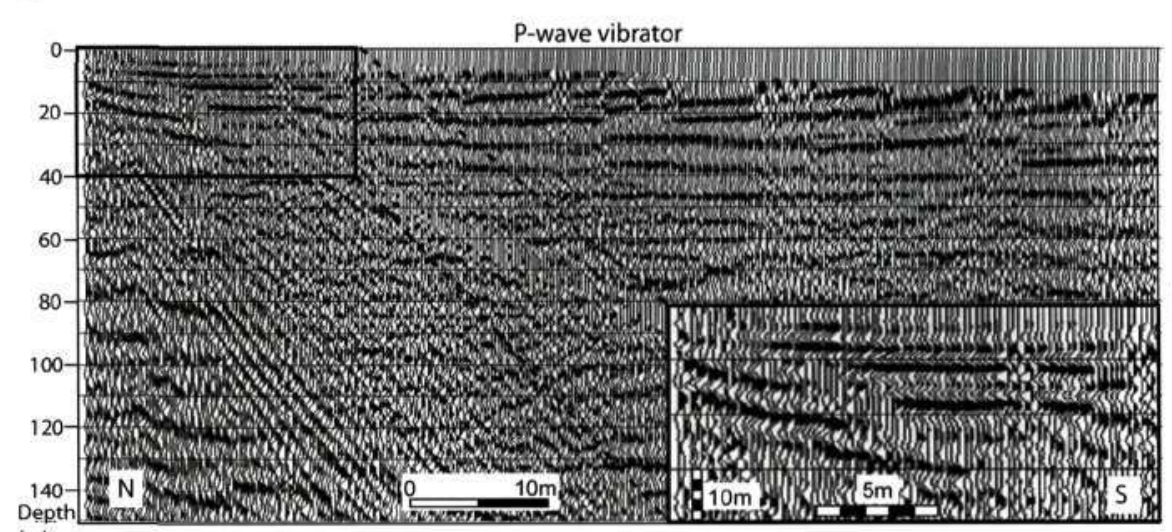

b. (m) number of irregular structures with lower resistivity were often observed. The latter could possibly be related to paleo-channel fills with a constitution different from the surrounding material.

The DC resistivity results did not give reliable information on the presence of peat or clay layers. Field work was extremely strenuous and acquisition time therefore ran over several tidal cycles. Tide-induced variations in salinity and groundwater level could therefore not be avoided, which made it difficult to distinguish lithological variations from hydrogeological features.

\section{Electromagnetic investigations on land}

As was the case for the $\mathrm{DC}$ resistivity data, the interpretation of the TEM data was equally influenced by the effect of tidal action and accompanying water intrusion on the salinity of the pore content and consequently on the resistivity of the layers. Nevertheless, the inverted TEM profiles proved to show more stratification than the DC resistivity profiles, although the resistivity contrasts were still very low.

On the marsh profile (Fig. $8 \mathrm{~b}$ ) the dike stands out clearly with resistivity values between 3 and $10 \mathrm{ohm} \cdot \mathrm{m}$. It presumably consists of sand. Below the dike, and along roughly the entire profile, a shallow low-resistivity layer was observed at a depth of 3 to $5 \mathrm{~m}$. The latter may indicate saline-water saturated soil, but it could also indicate the presence of a peat-rich layer. Peat is typically saturated and largely composed of water, and may therefore show a higher conductivity than the surrounding dryer sediments. The highly decomposed plant material within peat has a high surface charge, which could further increase the conductivity (Slater \& Reeve, 2002). Below this low-resistivity layer a thick layer of higher resistivity is observed, which thickens towards the east.

\section{Marine resistivity investigations}

The inverted resistivity profiles did not show sharp resistivity contrasts but rather a gradual horizontal stratification (Fig. 8c), indicating a steady increase in resistivity values of the deeper sediments. The latter suggests an increasing compaction (less water between the pores causing higher resistivity). Again the high conductivity resulted in a decrease of the reliability of the deeper data (the latter being less sensitive to variations in resistivity). In general depths up to $8-10 \mathrm{~m}$ allowed the construction of a reliable inverted resistivity model. Some profiles showed a very low resistivity even for deeper sediments, suggesting the presence of sand layers with a high porosity, or perhaps substantial clay layers.

The transition from water layer to upper sediments remained unclear, suggesting a smooth increase in density before compacted soil is reached. Moving deeper into the tidal flat area the water layer often showed an increase in resistivity, most likely reflecting the increased presence of fresh water. Local variations in resistivity of the water layer could indicate changes in salinity (temperature remained rather constant), but could to a certain extent also be a result of poor contact between the electrodes and the water (e.g. due to wave action). 

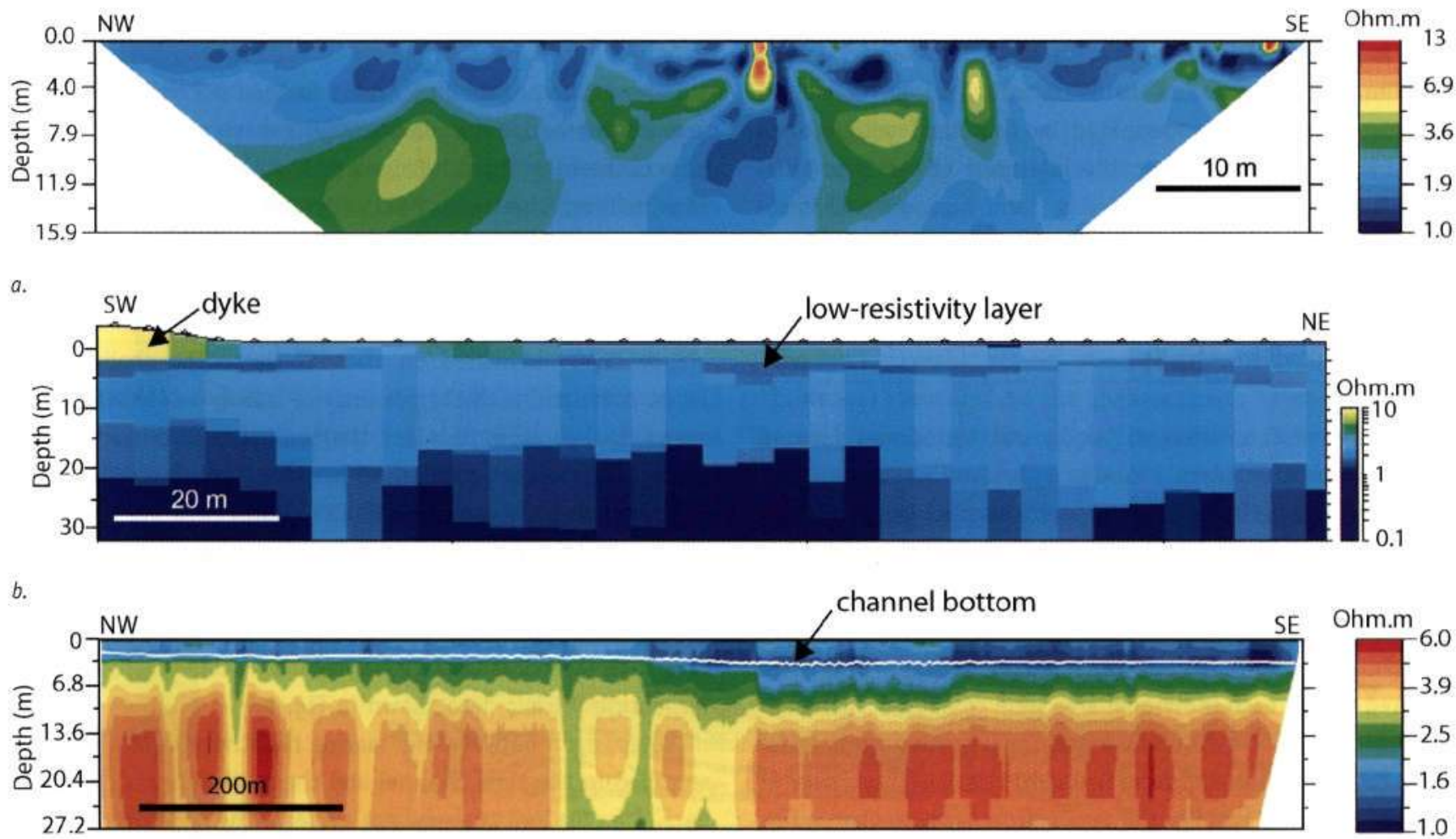
c.

Fig. 8. Geo-electric (DC resistivity) and electromagnetic (TEM) profiles in the tidal flat area (for location see Fig. 3). a. Inverted $D C$ resistivity section across the tidal marsh; inverse Schlumberger array, $1 \mathrm{~m}$ spacing. No well-defined horizontal stratification is observed. The shallow high resistivity features coincide with small active channels. Deeper high resistivity features possibly refer to buried tidal channel deposits; $b$. Inverted TEM section across the tidal marsh (12.5 $\mathrm{m}$ loop size). The (sandy) dike stands out clearly on the left with high resistivity values. $A$ low resistivity layer is observed at $3-5 \mathrm{~m}$ depth, possibly indicating salinewater saturated soil or a shallow peat layer; $c$. Inverted marine $D C$ resistivity section in the eastern tidal channel; dipole-dipole array, $6 \mathrm{~m}$ electrode spacing. The white line indicates the channel floor. The transition from water to sediments is very vague, indicating highly watersaturated channel-floor sediments.

\section{Coring and CPT}

All suction cores are characterised by the presence of a compact peat layer at the base (Fig. 9a). Most likely this peat layer prevented deeper penetration. The presence of a peatrich layer was also indicated on the CPT profiles further north in the tidal channel, its thickness there ranging from $40 \mathrm{~cm}$ to $1.5 \mathrm{~m}$ (Fig 9a). The friction ratios above the peat layer suggest medium to fine sandy sediments with clayey and silty layers (Fig. 9a, CPT2), becoming more sandy towards the shoal (Fig. 9a, CPT2). Below the peat layer a more uniform sandy sequence seems to be present.

The manual cores show the large variety in lithofacies over a short distance across the tidal channel. The marsh succession on the cut bank (Fig. 9b, core SC1) shows a gradual fining

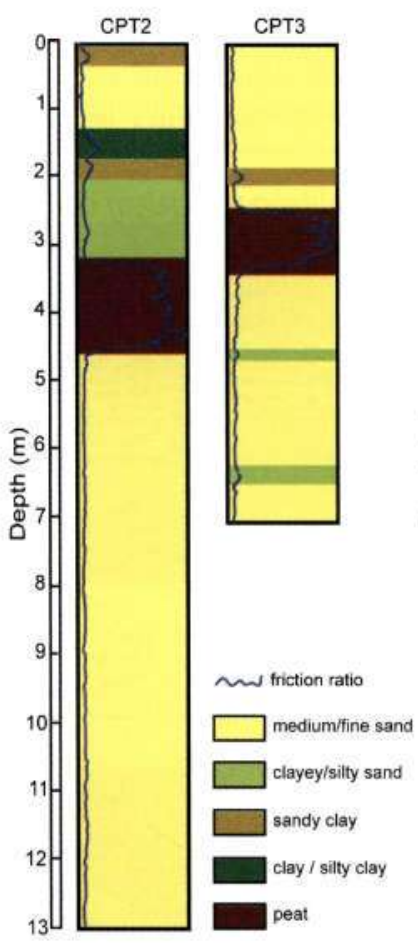

a.

Figure 9. a. Interpreted CPT profiles recorded in the main tidal channel (for location see Fig. 3). All profiles are marked by a clearly distinguishable peat-rich layer. b. Suction cores acquired in/along the main tidal channel (for location see Fig. 3) (core SC1: on the supra-tidal marsh; core SC2: in the tidal channel). The cores are marked by a peat layer at the base. 
upward from homogeneous very-fine clayey sand and silt with shell fragments and plant roots, to sandy clay and clay. The cores in the channel and on the shoal (Fig. 9b, core SC2) comprise a succession dominated by fine sand with broken shell fragments. The core on the high part of the inter-tidal point bar shows an upward change form homogeneous fineand very-fine sand to laminated very-fine sand and silt.

\section{Comparison and integration of different geophysical methods}

Comparison of the different geophysical techniques focused on two small areas (Area 1 \& Area 2) located in the westernmost tidal gully (Fig. 3). Due to practical problems it was not possible to acquire all the data in the same location. Area 2 is located roughly $1 \mathrm{~km}$ landward from Area 1 in the tidal gully. Because the variability in the shallow subsurface in an active sedimentary environment is expected to be high, only data acquired within each individual area were compared. Although the latter did involve different depositional environments (tidal gully, intertidal flat, supra-tidal marsh) the close proximity of the recorded data within each area (often no more than a few tens of $\mathrm{m}$ ) seems to justify this comparison. In doing so, however, we should also keep in mind that the lithological and sedimentological variability within each depositional environment is expected to be smaller than the variability between different environments.

\section{Area 1}

Different data acquired in Area 1 include CPT, marine seismic and marine resistivity profiles. An overview of some of the data is shown in Fig. 10. Comparison of the CPT data (Fig. 10c) obtained on the sand flat with the marine seismic data (Fig. 10a) obtained nearby in the tidal channel showed an overall good correspondence. The shallow reflectors observed on the seismic profiles seem to correlate well with the thin clayey layers indicated on the CPT data. The shallow peat layer, combined with the presence of mainly sandy sediments, seems to be responsible for the limited penetration of the seismic data. Exact correlation between the observed seismic reflectors and the interpreted CPT profile was very difficult due to the lateral displacement (be it very small) between the seismic and CPT measurements (ranging from $20 \mathrm{~m}$ to $100 \mathrm{~m}$ ), in view of the high lateral variability in subsurface sediments. This high lateral variability was clearly visible on the pseudo3D marine seismic data shown in Fig. 6 .

Comparison between the marine resistivity data (Fig. 10b) recorded in the tidal channel and the marine seismic and CPT data (Fig. 10a and 10c) was not evident. The resistivity profiles were marked by a much lower resolution, and often lacked any clear stratigraphic layering. The latter however seemed to confirm the presence of a rather uniform sandy sequence without extensive clay layers (indeed the clay intercalations inferred from the CPT data were very thin). The marine

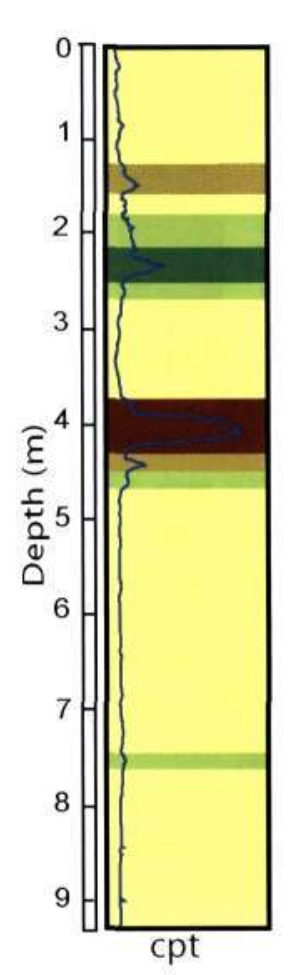

c. marine seismic profile

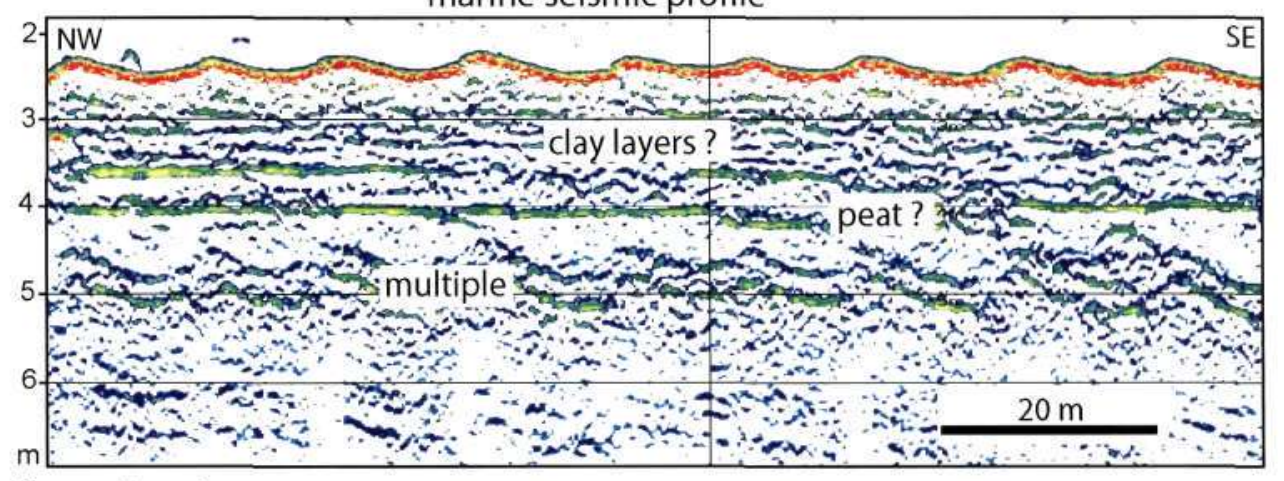

a. Area 1
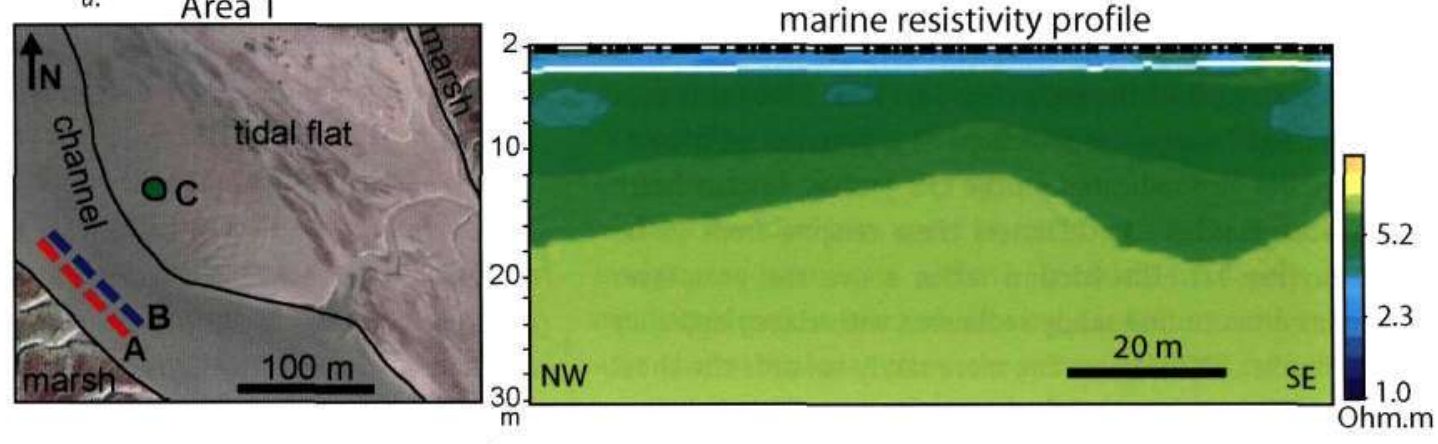

$b$.

Fig. 10. Results from different geophysical measurements in Area 1 (for location see Fig. 3). The data were adjusted to the same vertical datum. a. Marine seismic section (parametric profiler); b. Marine $D C$ resistivity section (white line $=$ channel floor); $c$. CPT profile (description of symbols and colours see Fig. 9A). The location of the different data is shown at the bottom left. A full discussion is given in the text. 
resistivity data did not reveal the presence of the peat layer, despite its significant thickness in the area (up to $1.5 \mathrm{~m}$, see Fig. 9). This is perhaps not surprising since peat is typically saturated and its conductivity will show a high dependence on fluid conductivity (Comas et al., 2004 and references therein). As the surrounding sediment in the tidal channel will be highly water-saturated the contrast with peat is likely to be very low.

\section{Area 2}

Different data acquired in Area 2 include marine seismic and resistivity profiles, land seismic data, land DC resisitivity and TEM data, and shallow cores. An overview of some of the data is shown in Fig. 11. The suction core (Fig. 11d) is located at the end of the seismic walk-away profile on the sand bar. The shallowest reflections, observed at 1 and $3 \mathrm{~m}$ depth on the $\mathrm{S}$ wave vibrator data (Fig. 11c), seem to correspond well with the clay-rich layers in the core. The strong seismic reflection at $4 \mathrm{~m}$, observed both on the S-wave and P-wave vibrator data (see also Fig. 8), suggests a good correlation with the shallow peat layer.

Adjacent marine seismic data (Fig. 11a) from the tidal channel also show the presence of several (often discontinuous) shallow reflectors. These reflections most likely correspond to the sand-clay-peat stratification (and possibly also dense shell horizons) identified on the shallow cores. As was the case for Area 1, also here exact correlation between the marine seismic data and shallow cores was not possible due the lateral displacement between the measurements and the high lateral variability in the shallow sediments.

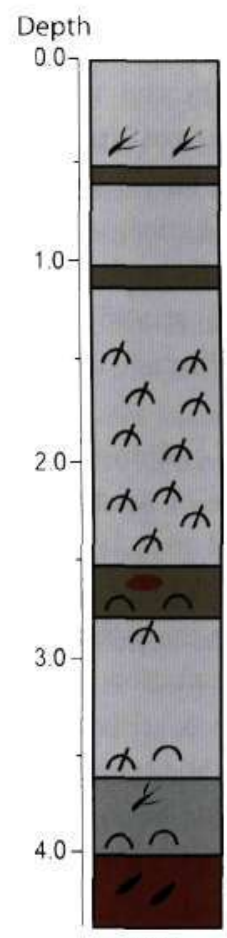

d. core

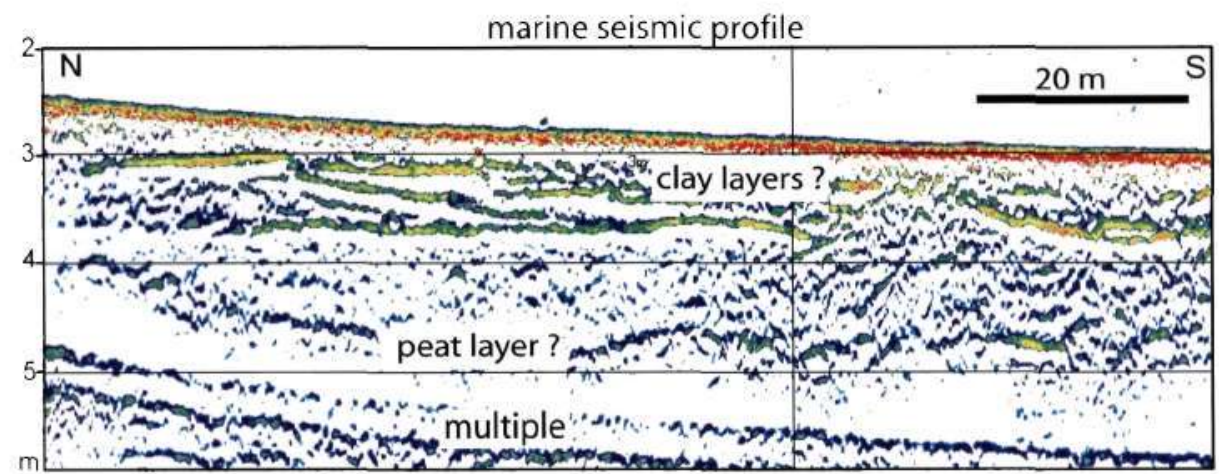

a.

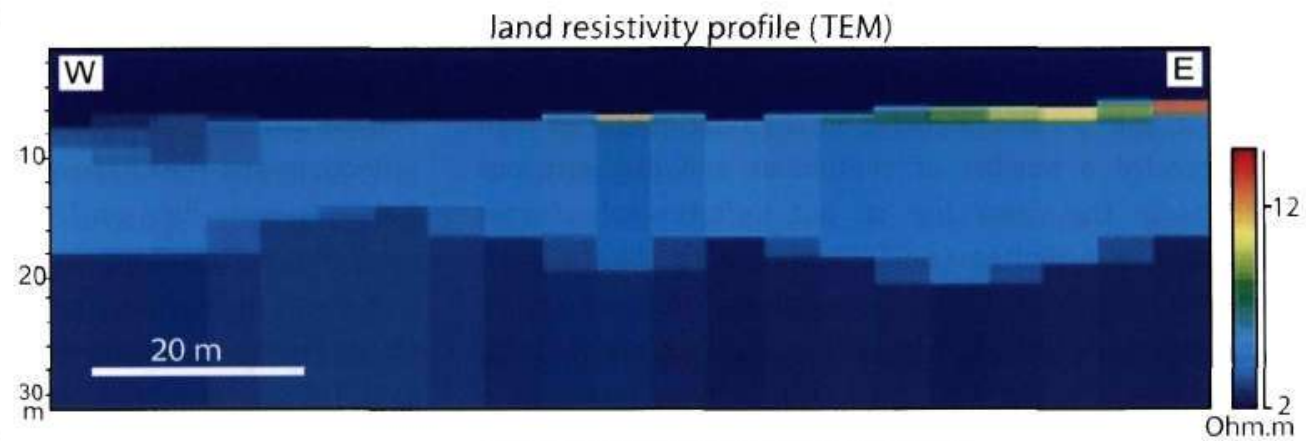

b.
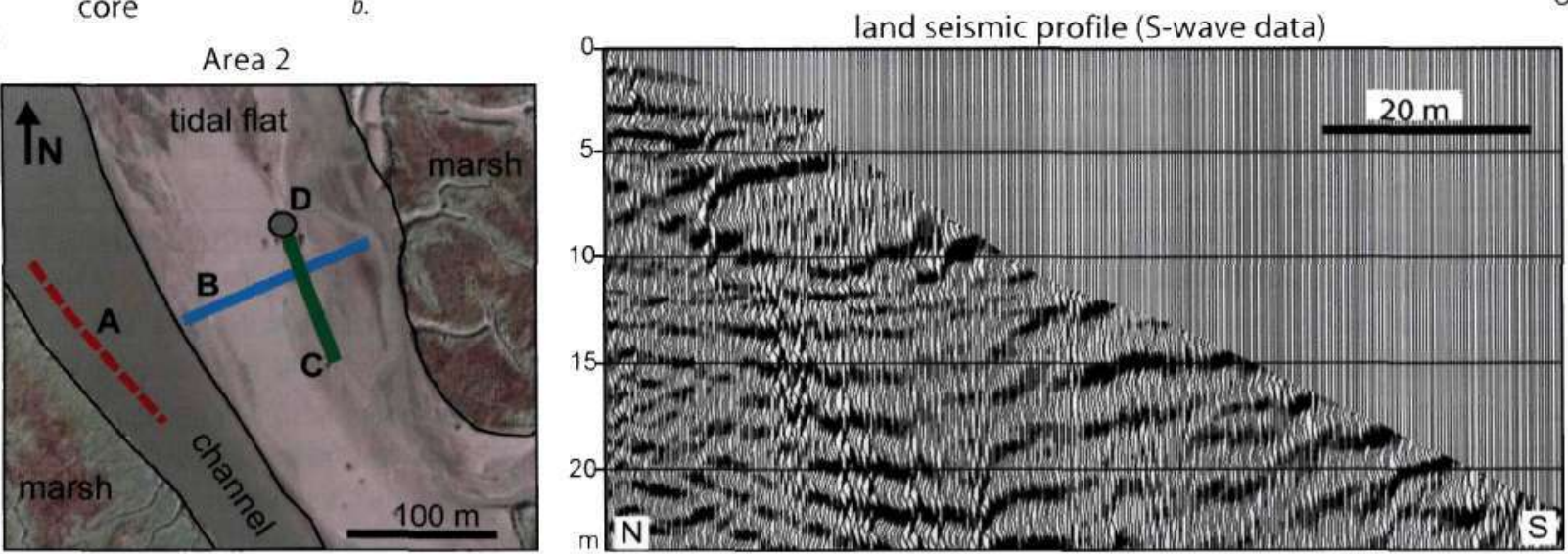

Fig. 11. Results from different geophysical measurements in Area 2 (for location see Fig. 3). The data were adjusted to the same vertical datum. a. Marine seismic section (parametric profiler); b. Land TEM section; c. Land seismic section (S-wave vibrator); d. Suction core profile (description of symbols and colours see Fig. 9). The location of the different data is shown at the bottom left. A full discussion is given in the text. 
The core data were also compared with resistivity data from nearby electromagnetic measurements (Fig. 11b). The TEM results on the marsh (see also Fig. 8b) suggest the possible presence of a shallow peat layer, which seems to correspond well with the core data. This low-resistivity layer is absent on the profile crossing the tidal channel (Fig. 11b), possibly due to the low resistivity contrast with the water-saturated sediments (as was the case for the marine resistivity data in Area 1) or erosion. Towards the marsh a thin high-resistivity layer stands out clearly on this TEM profile. The latter could possibly be related to a dense shell layer (indeed the presence of shell horizons is suggested on some of the cores). Its depth suggests a correlation with the reflector observed at a depth of $6-7 \mathrm{~m}$ on the land seismic data (Fig. 11c).

DC resistivity data, both on land and marine, did not give much additional information. The resolution was very low, and no clear stratification was observed. Again, the latter may confirm the presence of a relatively uniform sandy sequence without marked clay layers. The DC resistivity profiles on the marsh (see Fig. 8a) showed a number of shallow, lowerresistivity areas, but it is not sure whether these are actual lithological structures or whether they are artifacts caused by variations in salinity and groundwater level.

\section{Discussion and conclusions}

In general the seismic techniques allowed a better interpretation of the shallow sedimentary structures compared to the geoelectric and electromagnetic methods. The very high resolution marine seismic profiles, recorded in the tidal gullies at high tide, revealed a number of continuous and discontinuous reflectors in the upper few $\mathrm{m}$, but unfortunately deeper penetration was limited (most likely due to shallow gas). Parametric echosounder data provided the sharpest image, with a vertical resolution of $15-20 \mathrm{~cm}$. The land seismic data, recorded on a sand bar in the main tidal channel, revealed the presence of different shallow reflectors in the upper $10 \mathrm{~m}$, in addition to a large number of deeper reflections. The shallowest reflections likely correspond to recent Walcheren Member deposits (tidal sands with clay intercalations) and Holland peat deposits. Shear-wave data provided the best vertical resolution, roughly around $40-50 \mathrm{~cm}$.

The resistivity methods, applied both on land (supra-tidal marsh and intertidal flat) and on the water, mostly did not allow a clear identification of the shallow stratification. The measurements suffered from the effect of tidal action and saltwater intrusion, making it difficult to distinguish lithological variations from background signatures related to hydrogeological features; furthermore the application of these techniques on the tidal flat proved very strenuous. Vertical resolution of the resistivity methods was well over $1 \mathrm{~m}$. The electromagnetic data (TEM) overall provided better results than the geo-electric measurements, often showing some weak internal layering although still with a much lower resolution compared to the acoustic data (roughly $1 \mathrm{~m}$ ).

Comparison between marine resistivity data and marine seismic profiles from the tidal gullies was not fruitful. Penetration of the seismic data was limited to only a few $m$, at best. Furthermore the large difference in horizontal and vertical resolution between the two data sets did not allow a good correlation. As expected, the detailed stratification observed on the seismic data was not reflected in the resistivity values.

Shallow cores and CPT, taken on the marsh and on a sand bar in the main channel, revealed a sequence of sandy and clayey deposits and the presence of a marked peat layer of varying thickness. Comparison with seismic data, both land and marine, suggests a good correlation between the shallowest reflections and the CPT/core data. The high resolution of the S-wave seismic data on land, and their high sensitivity to small changes in soil type, allowed to observe subtle transitions from sandy to sandy clay sediments that could not be observed on the P-wave data. However the resolution of the land seismic data (40 $\mathrm{cm}$ at best) was probably too low to allow the identification of very thin clay layers.

Table 1. Advantages and disadvantages of the different geophysical methods tested in the Verdonken Land van Saeftinge.

\begin{tabular}{|c|c|c|}
\hline Method & Advantage & Disadvantage \\
\hline Marine seismic profiling & very high resolution, fast method & $\begin{array}{l}\text { Only deeper gullies, penetration limited due to shallow } \\
\text { gas, multiples }\end{array}$ \\
\hline Land seismic profiling & $\begin{array}{l}\text { high resolution, deep penetration, } \\
\text { S-wave data not affected by shallow gas }\end{array}$ & slow method, recording on sand flats limited by the tide \\
\hline Marine geo-electric profiling & fast method, not affected by shallow gas & $\begin{array}{l}\text { very low resolution, data highly affected by changing } \\
\text { salt concentration }\end{array}$ \\
\hline Land geo-electric profiling & deep penetration, not affected by shallow gas & $\begin{array}{l}\text { low resolution, strenuous method, data highly affected } \\
\text { by tide and salt intrusion }\end{array}$ \\
\hline Land TEM profiling & medium resolution, not affected by shallow gas & strenuous method \\
\hline Manual coring & very high resolution & strenuous method, limited depth, 1D data \\
\hline CPT & very high resolution & strenuous method, limited depth, 1D data \\
\hline
\end{tabular}


One of the main difficulties was to correlate different data that were not recorded exactly on the same spot. The high lateral variability in the shallow sediments, even within the same depositional environment, was clearly revealed in the cores and CPT's and on the seismic data. Due to this high variability a precise 'one-on-one' correlation between different data sets, even if they were obtained a few tens of meters apart, was sometimes difficult. This high variability is also confirmed by a recent study by Robb et al. (2005) which shows that intertidal and submerged sediments often have different properties (e.g. the rigidity of intertidal sediments is less than that of submerged sediments). Nevertheless in many cases a good correlation was observed between the datasets. Shallow peat deposits formed a strong marker and stood out clearly on the recorded data from different depositional environments. Also thin clay-rich layers could often be traced between the different records (e.g. land \& marine seismic and core data in Area 2).

The land-based and marine seismic data showed some variability in acoustic data quality. Partly this could be due to the presence of shallow gas. But the variability was also observed in (assumed) gas-free areas and on the S-wave seismic data, suggesting a high level of heterogeneity in the shallow sediments. This seems to confirm recent studies by Robb et al. (2006) who observed that intertidal sediments are often marked by a great variability in acoustic parameters over distances on meter-to-decimeter scale, especially in sandy areas which are marked by a greater variability in attenuation coefficient.

The results of this test-study clearly indicate that not one single geophysical technique can provide all the answers. A combination of seismic techniques, both on land and marine, together with well-placed ground-truth coring and CPT, is likely to provide the best strategy to image recent sedimentation processes in active tidal flat areas that are prone to large variations in water salinity. The difficult terrain conditions demand a creative and careful survey design using lightweight equipment and small, shallow draft boats. This inventive use of complementary geophysical methods should finally allow to get a better grip on sedimentation rates and preservation potential in these environments, a prerequisite to start validating numerical morphodynamic and stratigraphic models.

\section{Acknowledgements}

The authors would like to thank the following persons and institutions for their assistance during the numerous field tests and subsequent data processing: Ilja de Winter, Hanjo Reinink, Olaf Heijnen, Allan Redjosentono, Ranajit Ghose, Alber Hemstede, Irina 0vereem, Albert Kettner, Joep Storms (all at Delft University of Technology), Wim Versteeg, Koen De Rycker (Gent University), Henk van der Meer, Esther Stouthamer (Utrecht University), Andre Cattrijse, Francesco Hernandez, Arnold Vereecken, Jens Lowag, Veerle De Swaef, Vlaams Instituut voor de Zee, ZDO RIKZ, Katholieke Hogeschool St. Lievens Gent.

\section{References}

Allen, J.R.L., 1982. Mud drapes in sand wave deposits: a physical model with application to the Folkestone Beds (early Cretaceous, southeast England). Philosophical Transactions of the Royal Society of London, A 306: 291-345.

Baker, G.S., Schmeissner, C. \& Steeples, D.W., 1999. Seismic reflections from depths of less than 2 meters. Geophysical Research Letters 26(2): 279-282.

Comas, X., Slater, L. \& Reeve, A., 2004. Geophysical evidence for peat basin morphology and stratigraphic controls on vegetation observed in a Northern Peatland. Journal of Hydrology 295: 173-184.

De Brouwer, J., Crosato, A., Dankers, N., van Duin, W., Herman, P.M.J., Van Raaphorst, W., Stive, M.J.F., Talmon, A.M., Verbeek, H., De Vries, M.B., Van der Wegen, M. \& Winterwerp, J.C., 2001. Eco-morphodynamic processes in the Rhine-Meuse-Scheldt delta and the Dutch Wadden Sea. Delft Hydraulics report Z2817: 93 pp.

De Gans, W. \& Van Gijssel, K., 1996. The Late Weichselian morphology of the Netherlands and its influence on the Holocene coastal development. In: Beets, D.J., Fischer, M.M. \& De Gans, W. (eds): Coastal studies on the Holocene of the Netherlands. Mededelingen Rijks Geologische Dienst N.S. 57: 11-25.

De Kraker, A.M.J., 1997. Landschap uit Balans. De invloed van de natuur, de economie en de politiek op de ontwikkeling van het landschap van de Vier Ambachten en het Land van Saeftinge tussen 1488 en 1609 (in Dutch). Uitgevery Matrijs, Utrecht: 464 pp.

Donselaar, M.E. \& Geel, C.R., 2007. Facies architecture of heterolithic tidal deposits: the Holocene Holland Tidal Basin. Netherlands Journal of Geosciences 86: $389-402$.

Ebbing, J.H.J. \& Laban, C., 1996. Geological history of the area off Walcheren and Zeeuws-Vlaanderen (southwestern Netherlands) since the start of the Eemian. In: Beets, D.J., Fischer, M.M. \& De Gans, W. (eds): Coastal studies on the Holocene of the Netherlands. Mededelingen Rijks Geologische Dienst N.S. $57: 251-268$.

Ghose, R., 2003. High-frequency shear-wave reflections to monitor lateral variations in soil, supplementing downhole geotechnical tests. In: Saveur, J. (ed.): Proceedings of ITA world tunneling.

Ghose, R., Nijhof, V., Brouwer, J., Matsubara, Y., Kaida, Y. \& Takahahi, T., 1997. Shallow to very shallow, high-resolution reflection seismic using a portable vibrator system. Geophysics 63(4): 1295-1309.

Jongerius, P. \& Helbig, K., 1988. Onshore high-resolution seismic profiling applied to sedimentology. Geophysics 53(10): 1276-1283.

Kogan, I. \& Paull, C.K., 2004. Coastal seismic wipe-outs - distribution controlled by pore waterc salinity. Marine Geology 217: 161-175.

Lunne, T., Robertson, P.K. \& Powell, J., 1997. Cone Penetration Testing in Geotechnical Practice, E \& FN Sponn, London: 1-312.

Maillet, G.M., Rizzo, E., Revil, A. \& Vella, C., 2005. High resolution electrical tomography (ERT) in a transition zone environment: Application for detailed internal architecture and infilling processes study of a Rhone River paleochannel. Marine Geophysical Researches 26: 317-328.

Méndez, G., Pérez-Arlucea, M., Stouthamer, E. \& Berendsen, H., 2003. The TESS-1 suction corer: a new device to extract wet, uncompacted sediments. Journal of Sedimentary Research 73: 1078-1081.

Nio, S.D., Siegenthaler, C. \& Yang, C.S., 1983. Megaripple crossbedding as a tool for the reconstruction of the palaeohydraulics in a Holocene subtidal environment, SW Netherlands. Geologie \& Mijnbouw 62: 499-510. 
Nio, S.D. \& Yang, C., 1991. Diagnostic attributes of clastic tidal deposits: a review. In: D.G. Smith, D.G., Reinson, G.E., Zaitlin, B.A., Rahmani, R.A. (eds): Clastic Tidal Sedimentology, Canadian Society of Petroleum Geologists Memoirs 16: 3-27.

Robb, G.B., Dix, J.D., Best, A.I., Bull, J.M., Leighton, T.G., White, P.R. \& Seal, A., 2005. The compressional wave and physical properties of intertidal marine sediments. In: Proceedings of the 1st International Conference on Underwater Acoustic Measurements: Technologies \& Results, Heraklion, Crete, Greece. Foundation for Research \& Technology - Hellas: 1087-1092.

Robb, G.B., Best, A.I., Dix, J.D., Bull, J.M., Leighton, T.G. \& White, P.R., 2006. The frequency dependence of compressional wave velocity and attenuation coefficient of intertidal marine sediments. Journal of the Acoustical Society of America 120(5): 2526-2537.

Slater, L. \& Reeve, A., 2002. Investigating peatland stratigraphy and hydrogeology using integrated electrical geophysics. Geophysics 67(2): 365-378.

Van Damme, S., Struyf, E., Maris, T., Ysebaert, T., Dehairs, F., Tackx, M. Heip, C. \& Meire, F., 2005. Spatial and temporal pattens of water quality along the estuarine salinity gradient of the Scheldt estuary (Belgium and the Netherlands): results of an integrated monitoring approach. Hydrobiologia 540: 29-45.

Van de Meene, E.A., Van der Staay, J. \& Teoh Lay Hock, 1979. The Van der Staay suction-corer - a simple apparatus for drilling in sand below groundwater table. Rijks Geologische Dienst, Haarlem: 1-15.

Van der Spek, A.J.F., 1997. Tidal asymmetry and long-term evolution of Holocene tidal basins in the Netherlands: simulation of palaeo-tides in the Schelde estuary. Marine Geology 141: 71-90.

Verlaan, P.A.J., Donze, M. \& Kuik, P., 1997. Marine vs Fluvial Suspended Matter in the Scheldt Estuary. Estuarine, Coastal and Shelf Science 46(6): 873-883.

Vos, P.C. \& van Heeringen, R.M., 1997. Holocene Geology and occupation history of the Province of Zeeland. In: Fisher, M.M. (ed.): Holocene evolution of Zeeland, TNO 59: 5-109.

Weerts, H.J.T., Cleveringa, P., Ebbing, J.H.J., Lang, F.D. \& Westerhoff, W.E., 2000. De lithografische indeling van Nederland. Formaties uit het Tertiair en kwartair. TNO-NITG rapport 00-95-A. TNO-NITG, Utrecht: 38 pp. 